\title{
Odnos episkopske i svećeničke službe u pravoslavlju
}

\author{
ZLATко MATIĆ* \\ UDK: 271.2 • Izvorni znanstveni rad \\ Primljeno: 22. listopada 2017. • Prihvaćeno: 18. lipnja 2018.
}

${ }^{*}$ Doc. dr. sc. Zlatko Matić, Pravoslavni bogoslovni fakultet Sveučilišta u Beogradu, Mije Kovačevića 11b, 11060 Beograd, Srbija, zmatic@bfspc.bg.ac.rs

Sažetak: Članak predstavlja analizu osnovnih elemenata teološke perspektive u kojoj autor sagledava delikatan problem odnosa episkopske i prezbiterske službe u pravoslavlju. Najprije predstavlja episkope i prezbitere onako kako ih Pravoslavna Crkva sagledava upravo na temelju euharistijske (eshatološke) bogoslovne vizije, da bi se u trećem dijelu svoga istraživanja osvrnuo na suvremenu situaciju u Pravoslavnoj Crkvi. Na kraju iznosi neke svoje zaključke koji bi mogli pomoći crkvenim pastirima u analizi mogućega napretka u boljem razumijevanju svih službi u Crkvi i njihova odnosa u jednom istom organizmu, Tijelu Kristovu. Primjereno razumijevanje tih odnosa uvjetovano je i crkvenom situacijom i krizom službi, ali i novim sociopolitičkim okolnostima pluralističkoga društva.

Ključne riječi: episkop, prezbiter, crkvene službe, eshatologija, hirotonija, $\gg k o i n o n i j a \ll$.

\section{Uvod}

Govoriti o određenoj temi s pravoslavne točke gledišta, analizirati konkretnu tematiku iz perspektive pravoslavne teologije, pravoslavlja ili Pravoslavne Crkve, višestruko je težak i osjetljiv zadatak. Prije trideset godina vodeći živi pravoslavni teolog metropolit pergamski Ioannis Zizioulas, odgovarajući na sličan izazov, u svoju obranu navodi to da pravoslavlje nema svoj Drugi vatikanski koncil ni specifična ispovijedanja vjere ni vjerske vođe, utemeljitelje denominacije. Osobitost pravoslavlja ista je kao i u ostalim kršćanskim zajednicama, a to su Biblija i oci. Zato metropolit naglašava da je odgovarajući odgovor na bilo koju temu koju treba obraditi s pravoslavnoga gledišta, zapravo, 
onaj kojim se precizno utvrđuju središnji momenti teološke perspektive ili, drugim riječima, onaj diskurs kojim se identificiraju teološke pretpostavke u kojima pravoslavno bogoslovlje sagledava zadani problem.

Tim ćemo se metodološkim prijedlogom i mi voditi u analizi jednoga dubokoga ekleziološkoga pitanja kao što je odnos episkopske i svećeničke službe u Pravoslavnoj Crkvi. Ponudit ćemo stoga najprije osnovne elemente teološke perspektive u kojoj ćemo sagledavati spomenuti osjetljivi problem. Nakon toga predstavit ćemo episkope i prezbitere onako kako ih Pravoslavna Crkva sagledava upravo na temelju toga bogoslovnoga viđenja, da bismo se u trećem dijelu ovoga istraživanja osvrnuli na suvremenu situaciju u Pravoslavnoj Crkvi. Na kraju ćemo iznijeti neke svoje zaključke koji bi mogli pomoći crkvenim pastirima u analizi možebitnoga napretka u razumijevanju svih službi u Crkvi i njihova odnosa u jednom istom organizmu, Tijelu Kristovu. Vjerujemo da na taj način objavljujemo i sam razlog postojanja teologije i teologa, a on je - služenje Crkvi u njezinu hodu prema Kristovu dolasku i konačnomu ukidanju smrti.

\section{Episkopska i prebiterska služba u Crkvi: teološka (ekleziološka) perspektiva}

1. Polazna je točka svih eklezioloških analiza u pravoslavlju središnji događaj života vidljive Crkve, služenje euharistije lokalne Crkve, kojim predsjedava episkop, okružen svojim prezbiterijem, đakonima i narodom Božjim. Njihov sinaksis ( $\dot{\varepsilon} \pi \dot{~}$

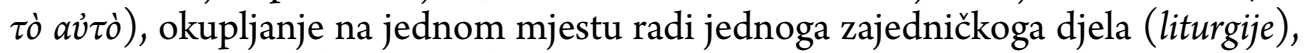
prinošenja darova (euharistija) Bogu i Ocu Gospodina Isusa Krista, u različitostima službi jednoga Duha, zaslužuje naziv Crkva jer ta struktura vjerno oslikava eshatološko stanje tvari, buduće kraljevstvo Božje. Euharistijski okvir sagledavanja ekleziologije upućuje nas na egzistencijalno, bogoslovno, konkretno - eshatološko razumijevanje njezine institucionalne povijesne organizacije, a time i njezinih služ$\mathrm{bi}^{1}$. Potrebe praktičnoga i organizacijskog tipa koje je nametala povijesna sociopolitička situacija smatrat ćemo sekundarnima u odnosu na spomenute teološke izvore razumijevanja službi u Crkvi. Budući da je euharistijska zajednica slika kraljevstva nebeskoga, jasno je da i njezin ustroj oslikava buduću realnost, »poredak sveta u kome Bog vlada $\ll^{2}$. Euharistijsko ili eshatološko iskustvo Crkve, kao ikonizacija trojstvene koinonije, prioritetno je u svim promišljanjima pojedinih crkvenih službi

\footnotetext{
${ }^{1} \gg$ Kao manifestacija jedinstva i celosnosti Crkve, evharistija je služila i kao krajnja bogoslovska norma crkvene organizacije ... «, J. MAJENDORF, Vizantijsko bogoslovlje. Istorijski tokovi i dogmatske teme, Kragujevac, 2008., 281.

${ }^{2}$ E. KLAPSIS, Svetotajinski karakter hirotonije i apostolskog prejemstva: pravoslavno-ekumenski pogled, u: Sabornost 12(2006.), 75-88., ovdje 83.
} 
i njihovih međusobnih odnosa. Sve povlastice, obveze, privilegije i prerogativi časti ili vlasti bilo kojega nositelja bilo koje službe izravno proizlaze iz neprikosnovenoga i nezamjenjivoga mjesta ( $\tau o ́ \pi o \varsigma)$ koje taj činitelj zauzima na liturgijskom okupljanju. Taj je ustroj Crkve ili euharistije hijerarhijskoga karaktera jer $\gg$ Duh Sveti utemeljuje Crkvu kao jerarhijsku zajednicu $\ll^{3}$. Na taj način postaje jasno da se odgovor na temu našega istraživanja, odnosa episkopa i svećenika, mora tražiti u okvirima te koncepcije, čije polazište pronalazimo u novozavjetnim spisima, a koju je prvi predstavio sveti Ignacije Antiohijski početkom II. stoljeća. Taj koncept temeljan je za Pravoslavnu Crkvu do današnjih dana. ${ }^{4}$

2. Episkop je u pravoslavnoj predaji po povlastici liturg, svećenik koji predvodi euharistijsko slavlje i prinosi darove liturgijske zajednice Bogu. ${ }^{5}$ To vjerovanje potvrđuju najranije molitve hirotonije episkopa, kao što je tekst iz Hipolitove Apostolske predaje. Jedino se pri rukopoloženju episkopa moli Bog i Otac Gospodina Isusa Krista da podari slugi svome koga je izabrao za episkopa da arhijerejstvuje (da služi kao prvosvećenik), služeći liturgiju danonoćno i »da prinosi darove Svete Crkve « Božje. ${ }^{6}$ Specifična je razlika episkopske službe (u odnosu na prezbitersku, đakon-

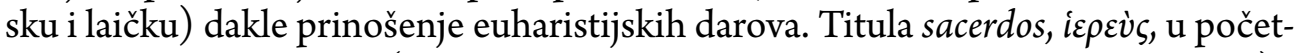
ku rezervirana za Krista (»Arhi-jereja velikog, koji je prošao nebesa «, Jevr 4, 14) 7 , vrlo brzo počinje se primjenjivati na episkope ${ }^{8}$ i sve do IV. stoljeća namijenjena je isključivo njima, a ne prezbiterima. Vodeći zajednicu koja Duhom Svetim postaje Krist, on vodi molitveni dijalog s Bogom Ocem, što u potpunosti potvrđuju liturgijske molitve jer su upućene Ocu. U molitvi hirotonije episkopa koja se danas upotrebljava u Pravoslavnoj Crkvi naime jasno se čuje: »Vladiko Gospode, Bože naš, ... /ovoga koji se rukopolaže/ pokaži ga svetim, da bi bio dostojan da od Tebe

${ }^{3}$ Usp. I. MIDIĆ, Duh Sveti i jedinstvo Crkve, u: Z. MATIĆ (ur.), Pravoslavna eklisiologija. Reč o Crkvi pred izazovima trećeg milenijuma, Požarevac, 2016., 93-121., ovdje 105.

${ }^{4}$ Metropolit Zizioulas tvrdi da bi, »uprkos odstupanjima nastalim usled mnogobrojnih istorijskih i teoloških promena, napuštanje ignjatijevskog principa za pravoslavlje značilo gubitak sopstvenog identiteta i sopstvene prirode «. J. ZIZIJULAS, Pravoslavlje, Beograd, 2003., 20.

${ }^{5} \gg$ Osnova episkopskog služenja nalazi se u samoj prirodi evharistijskog sabranja, gde je od samog početka postojalo jedno središnje mesto, što ga je zauzimala ista osoba «, zaključuje N. AFANASJEV, Crkva Duha Svetoga, Vršac, 2003., 402-403.

${ }^{6}$ Usp. A. JEVTIĆ (ur.), Dela apostolskih učenika, Vrnjačka Banja - Trebinje, 1999., 429.

${ }^{7}$ Koristili smo prijevod: Sveti arhijerejski Sinod SPC, Sveto Pismo. Novi Zavjet Gospoda našeg Isusa Hrista, Beograd, 1990.

${ }^{8}$ Upravo citirana molitva hirotonije iz Apostolske predaje izravno povezuje osobu i službu episkopa s arhijerejskim djelom. 
moli sve što je za spasenje naroda, a Ti da ga čuješ «. ${ }^{9}$ Upravo u tom euharistijskom ozračju, u kontekstu ljubavnoga dijaloga Oca i Sina, episkop se prepoznaje kao slika Kristova. ${ }^{10}$

Upravo tako sveti Ignacije Antiohijski govori o episkopu: $\gg$ Prema tome, jasno je da na episkopa treba gledati kao na samoga Gospoda $\ll{ }^{11}$, da mu se treba pokoriti $\gg$ kao Isusu Hristu $\ll^{12}$ jer tamo gdje je episkop, tamo je i mnoštvo (vjernih), baš kao što je i Crkva tamo gdje je Krist ${ }^{13}$. Ta simboličnost (slikovitost) ukazuje, prije svega, na poimanje lokalnoga episkopa kao korporativne ličnosti koji, slično Kristu, svojom službom, tj. kao predvodnik euharistijskoga slavlja, čuva i objavljuje katoličanstvo Crkve Božje na svim razinama. Krist nadilazi sve prirodne, biološke i društvene razlike ljudskoga roda i sobom sve sjedinjuje. U određenom prostoru to isto čini (trebao bi činiti) i episkop kao slika eshatološkoga, dolazećega Krista (Otk 1). Jedinstvo s episkopom postaje tako ontološka (u smislu - egzistencijalna) kategorija, » za obrazac i nauk besmrtnosti $\ll^{14}$. Budući da je jedan Krist, jedan je i episkop Crkve jednoga grada, jedan liturg jedinstvenoga Žrtvenika, tako da podvojenost titula uvijek označava raskol, šizmu ${ }^{15}$.

Episkop dakle zauzima Božje mjesto. Ignacije Bogonosac izričito kaže: »( ... čini-

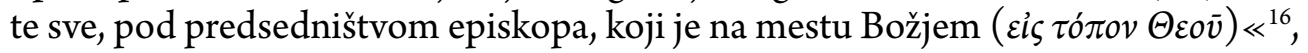
ili koji je »tip, slika Očeva ${ }^{17}$. Tim se mjestom objašnjava sva vlast koju jedan epi-

\footnotetext{
${ }^{9}$ Cijela molitva glasi: »Vladiko Gospode, Bože naš, Koji si nam preko svehvalnog Apostola Tvoga Pavla ozakonio poredak stepena i činova radi služenja i liturgisanja časnih i prečistih Tvojih Tajni na svetome Žrtveniku Tvome, prvo Apostole, drugo Proroke, treće Učitelje; Sam, Vladaru svih i svega, i ovoga izabranoga i udostojenoga da uzme na sebe jevanđelski jaram i arhijerejsko dostojanstvo, rukom mene grešnoga i saprisutnih mi saslužitelja i saepiskopa, nailaskom i silom i blagodaću Svetoga Duha Tvoga ukrepi, kao što si ukrepio svete Tvoje Apostole i Proroke, kao što si pomazao careve, kao što si posvetio prvosveštenike, i besprekornim posvedoči njegovo arhijerejstvo, i ukrašavajući svakom čestitošću, pokaži ga svetim, da bi bio dostojan da od Tebe moli sve što je za spasenje naroda, a Ti da ga čuješ. Jer se posveti Ime Tvoje i proslavi se Carstvo Tvoje, Oca i Sina i Svetoga Duha, sada i uvek i u vekove vekova.«

$10 \gg$ Episkop je, pre svega, ikona Hrista u evharistijskoj tajni «, J. MAJENDORF, Vizantijsko bogoslovlje, 281.

${ }^{11}$ IGNACIJE ANTIOHIJSKI, Efežanima, br. 6, 1.

${ }^{12}$ ISTI, Traljanima, br. 2, 1.

${ }^{13}$ ISTI, Smirnjanima, br. 8, 2.

${ }^{14}$ ISTI, Magnežanima, br. 6, 2.

${ }^{15}$ Usp. 8. kanon Prvog vaseljenskog sabora. To je motiv kojim se rukovode teolozi koji raskol Istoka i Zapada smještaju u 1204. godinu...

${ }^{16}$ IGNACIJE ANTIOHIJSKI, Magnežanima, br. 6, 1.

${ }^{17}$ ISTI, Traljanima, br. 3, 1.
} 
skop ima u mjesnoj Crkvi, koju vodi, koja se u njemu objavljuje, utjelovljuje ${ }^{18}$. Zbog toga mjesta $u$ zajednici episkop je neodvojiv od ostalih članova Crkve, bez njih on nije episkop. Uzimajući u obzir trijadološka načela pravoslavnoga bogoslovlja prema kojima su imena za osobe Presvetoga Trojstva nazivi za veze, odnose koji postoje među njima, ${ }^{19}$ tako da su sve Osobe povezane, može se zaključiti da episkopa nema bez ostalih službi, bez prezbitera, đakona i laika. On je episkop zahvaljujući onima koji dođu na liturgijsko slavlje i priznaju ga za svoga episkopa, svoga oca, slično vječnom priznanju Sina i Duha da je Bog njihov Otac. On nije jedinka koja po sebi, ex officio, nosi titulu arhijereja, nego je episkop određenoga grada, određenoga mjesta, nadziratelj konkretne zajednice. Od hirotonije, kada se mora naznačiti mjesto za čiju se crkvenu zajednicu vjenčava, ${ }^{20}$ on je episkop te konkretne mjesne Crkve, a ne episkop općenito. Kanoni strogo zabranjuju hirotoniju nenaznačenih episkopa ili drugih klerika ${ }^{21}$. Odmah po hirotoniji novorukopoloženi episkop preuzima predsjedanje euharistijom, kao što je bilo i u vrijeme nastanka Hipolitove Apostolske predaje, ${ }^{22}$ pa su se zato sva ređenja obavljala u gradu za koji se novi vladika postavlja.

Ta liturgijska slika episkopa kao slike Kristove, taj sakramentalni temelj autoriteta zasnovan na prvosvećeničkoj službi isključuje bilo kakvu ontološku hijerarhiju među episkopima. Mitropolit, arhiepiskop, patrijarh, ekumenski ili univerzalni primus uvijek je - episkop. Zato svi episkopi ostvaruju ekumensko zajedništvo sudjelovanjem na saboru koji se bavi svim pitanjima koja nadilaze područje interesa jedne eparhije, jedne mjesne Crkve. Budući da se u njegovoj mjesnoj Crkvi objavljuje sve-

18 »Pošto, dakle, u ime Božje, primih sve vaše mnoštvo u licu Onisima, u ljubavi neizrecivoga, a vašega u telu episkopa ... « (ISTI, Efežanima, br. 1,3), ili: »Udostojih se da vas vidim u licu Damasa, vašeg bogodostojnog episkopa, i dostojnih prezvitera.« (ISTI, Magnežanima, br. 2, 1) U liku episkopa Ignacije vidi punoću Crkve u Efezu, Magneziji itd. poistovećujući jednoga i mnoštvo.

${ }^{19}$ Spona (veza, schesis) je, prema učenju Grgura Bogoslova, relacijski termin kojim se identificiraju imena, tj. same osobe Presvetoga Trojstva i kojim se predstavlja trojstveni život kao osobna koinonija. $\gg$ Otac nije ni ime prirode, ni dejstva, nego ime odnosa «. GREGORIUS NAZIANZENUS, Orationes 29, 16, (PG 36, 95).

${ }^{20}$ U važećoj molitvi to glasi ovako: »Božanska blagodat... proizvodi tebe najbogoljubaznijeg arhimandrita, ili jeromonaha (ime) izabranoga za Episkopa Bogom čuvanog grada (gradova) (ime).«

${ }^{21}$ Usp. 6. kanon Kalcedonskoga sabora: »Bez naznačenja (neraspoređeno) ne treba rukopolagati nikoga, ni prezvitera, ni đakona, niti uopšte ikoga u crkvenom redu, nego rukopolagani da je posebno naznačen za Crkvu ... « »Zonara i Valsamon zapažaju: 'Kao što se za svakog arhijereja kaže da je izabran za taj i taj grad (Crkvu), tako je od starine svaki rukopolagani nazivan sveštenik ili đakon ili prosto klirik, te i te Crkve'«. A. JEVTIĆ (ur.), Svešteni kanoni Crkve, Beograd, 2005., 108.

${ }^{22}$ Nakon hirotonije i poljupca mira novom episkopu »dakoni donose prinos « i on blagodari, odnosno prinosi darove, prema kanonu euharistije. Usp. IPOLIT RIMSKI, Apostolsko predanje, br. 4, u: A. JEVTIĆ (ur.), Dela apostolskih učenika, Vrnjačka Banja - Trebinje, 1999., 427-458. 
opća Crkva, nijedan episkop ne može odvojiti brigu za svoju Crkvu od brige za sve mjesne Crkve (sollicitudo omnium Ecclesiarum) i za univerzalnu Crkvu. ${ }^{23}$ Taj stav pravoslavna predaja smatra izravnom posljedicom euharistijskoga ustroja Crkve jer što je drugo jedna euharistija lokalne Crkve ako nije eshatološko, univerzalno slavlje svih spašenih u gornjem Jeruzalemu. Na taj način episkop svojom službom objavljuje jedinstvo svoje mjesne Crkve, ali i njezino jedinstvo sa svim ostalim Crkvama širom svijeta. Od trenutka hirotonije, koju obavljaju »svi episkopi « određenoga područja ${ }^{24}$ (ili barem trojica, a naposljetku dvojica), vladika postaje spona lokalne i sveopće Crkve. U liku episkopa »i samo na taj način, lokalna Crkva nadilazi svaku provincijalističku i introvertnu orijentaciju i sjedinjuje se sa ostalim lokalnim Crkvama, u kinoniju jedne Crkve ${ }^{25}$.

3. Istinitost svih drugih crkvenih službi (osobito onih vječnih, konstitutivnih, a to su prezbiterska, đakonska i laička), jer episkop ne služi, ne odlučuje, ne sudi niti postoji izdvojeno od ostalih, pravoslavna predaja utvrđuje koinonijom s episkopom. Jednoga i jedinoga episkopa na euharistiji lokalne Crkve u početku je okruživao prezbiterij, sabor i savjet kao kolektivno tijelo. Ignacije Antiohijski usporedio je prezbitere $\mathrm{s} \gg$ dragoceno ispletenim duhovnim vencem $\ll^{26}$ koji treba biti u simfoniji s episkopom $\gg$ kao strune sa gitarom $\ll{ }^{27}$, time neumorno potvrđujući da episkop ne postoji bez njih. Više puta isti sveti otac tvrdi da su prezbiteri $\gg$ na mestu zbora apostolskog ${ }^{28}{ }^{28}$, da su oni $\gg$ sabor Božji i skup Apostola $\ll^{29}$ ili da je njima namijenjeno da slijede $\gg$ kao Apostolima $\ll^{30}$. Mjesto koje zauzima na liturgijskom slavlju, uz episkopa, ukazuje na to da prezbiterij simbolizira eshatološki nagovještaj apostolâ da sude, da budu porota kada Krist $\gg$ dođe sa slavom, da sudi živima i mrtvima «. Kao što je autoritet episkopa proizlazio iz eshatološkoga značenja koje on ima na euharistiji, tako se i status i uloga prezbiterija iščitava iz mjesta koje članovi toga ti-

${ }^{23}$ O ekumenskim dimenzijama pitanja zajedništva vidi Z. MATIĆ, Dokument iz Kjetija (2016): Sabornost i primat tokom prvog milenijuma, u: Sabornost 10(2016.), 89-100.

${ }^{24}$ Usp. 1. apostolski kanon: »Episkopa neka postavljaju dva ili tri episkopa.« Također, 4. kanon Prvoga nicejskoga sabora: »Episkop svakako treba da se postavlja od svih episkopa u oblasti; a ako to bude teško, ili zbog hitne potrebe, ili zbog daljine puta, neka se na svaki način trojica sakupe na jedno mesto, a odsutni neka svoj glas pristanka daju kroz pisma ... «

${ }^{25}$ S. JAGAZOGLU, »Kriza sabornosti - birokratsko shvatanje eklisiologije i problem zajednice i sabornosti Crkve danas «, u: Z. MATIĆ (ur.), Crkva kao ikona Svete Trojice. Bogoslovski simposion povodom jubileja Eparhije braničevske, Požarevac, 2014., 59-84., ovdje 66.

${ }^{26}$ IGNACIJE ANTIOHIJSKI, Magnežanima, br. 13, 1.

${ }^{27}$ ISTI, Efežanima, br. 4, 1.

${ }^{28}$ ISTI, Magnežanima br. 6, 1; usp. ISTI, Filadelfijcima, br. 5, 1.

${ }^{29}$ ISTI, Traljanima, br. 3, 1.

${ }^{30}$ ISTI, Smirnjanima, br. 8, 1. 
jela zauzimaju na crkvenom liturgijskom slavlju. Molitve rukopoloženja prezbitera iz vremena rane Crkve ponovno nam otkrivaju ključne elemente njegove službe. Apostolska predaja podsjeća na to da kada se rukopolaže prezbiter episkop postavlja ruku na njega, ali i na to da ga svi prezbiteri dotiču. Od Boga Oca episkop za novoga prezbitera traži $\gg$ Duha saveta prezviterstva, da bi štitio i rukovodio narod $\ll{ }^{31}$ Božji čistim srcem. Tako on dobiva $\gg$ zajednički Duh prezviterijuma $\ll^{32}$. Prezbiteri poučavaju narod i štite ga, nastavljaju apostolsku službu, imaju didaktičku i savjetodavnu službu, ali se ne spominje njihovo predvođenje euharistije. Slično apostolskoj misiji, njihova je uloga izrazita između dvaju nedjeljnih euharistijskih slavlja. ${ }^{33}$

$S$ druge strane u današnjoj molitvi rukopoloženja prezbitera za njega episkop moli, osim $\gg$ da neporočno stoji pred žrtvenikom « Božjim, da »propoveda Jevanđelje Carstva, da sveštenodejstvuje reč istine « Božje, još i to »da prinosi darove i žrtve duhovne $\ll$ Bogu Ocu. Jasno je da je svećenik postao predvodnik i središte jednoga manjega euharistijskoga slavlja, pastir parohijske zajednice. Bitno episkopovo obilježje, njegovo služenje euharistije, njegovo imenovanje jerejem, u jednom povijesnom trenutku preneseno je na prezbitera. Budući da se $\gg$ u pisanim izvorima triju prvih vekova nigde ne koristi izraz 'jerej' da bi označio prezvitera $\ll^{34}$, crkveni povjesničari taj prijelaz povezuju, naravno, s nastankom parohija u III. stoljeću i njihovim jačanjem u IV. stoljeću. Povećanje broja kršćana u mirnom razdoblju Rimskoga Carstva, ali i crkveni progoni koji su uzrokovali dugotrajna odsustva episkopa (zatvaranja ili progonstva), utjecali su na potrebu da euharistijske ovlasti prezbitera rastu u smjeru njihove jerejske (svećeničke) vlasti i službe.

$\mathrm{Na}$ ovom mjestu otvara se i središnja problematika našega istraživanja, odnos episkopa i prezbitera koji je izravno povezan s pitanjem odnosa episkopske i prezbiterskih liturgija, s odnosom eparhije i parohija. Prezbiter, vidjeli smo, postaje središte slavlja, on počinje prinositi euharistiju. Iako se vrlo rano spominje mogućnost da netko drugi predvodi euharistijsko slavlje, što se može dogoditi jedino »ako episkop kome dozvoli $\ll^{35}$, to nije značilo poništenje načela jedan episkop - jedna litur-

${ }^{31}$ Usp. IPOLIT RIMSKI, Apostolsko predanje, br. 7.

${ }^{32}$ Usp. isto, br. 8.

${ }^{33}$ Njihovo vodeće mjesto na služenjima srijedom i petkom, koja se obavljaju radi pouke i katehizacije, uklapa se u tu postavku jer su skupovi tim danima bili bez savršavanja euharistijske tajne. Usp. Sokrat Sholastik, Istorija Crkve, 22: »U Aleksandriji čitaju Sveto Pismo, a učitelji ga tumače sredom i petkom. U te dane vrši se sve ono što obično biva na bogosluženju, samo se ne obavlja tajna, a taj običaj je u Aleksandriji od davnina, jer se zna da je tako postupao još Origen.«

${ }^{34}$ To tvrdi metropolit Ioannis Zizioulas u svojoj doktorskoj disertaciji: J. ZIZIJULAS, Jedinstvo Crkve u svetoj Evharistiji i u Episkopu u prva tri veka, Novi Sad, 1997., 211.

${ }^{35}$ IGNACIJE ANTIOHIJSKI, Smirnjanima, br. 8, 1. 
gija - jedna Crkva. Riječ je o iznimkama i one nisu trebale biti trajno rješenje. Crkva se na različite načine borila da očuva vjeru u to da je episkop jedini liturg lokalne Crkve, eparhije. Morala je, na neki način, ponazočiti episkopa na svakom euharistijskom slavlju kojim predsjedava svećenik. Najbolji pokazatelj te vjere svakako je praksa fermentuma, čiji je cilj potvrditi živu nazočnost u fizičkom odsustvu episkopa u prezbiterskoj liturgiji. Osim toga u pravoslavlju je zastupljeno spominjanje episkopa u najvažnijem trenutku anafore u kanonu euharistije, služenje liturgije na oltarskoj trpezi koju episkop posvećuje i na antiminsu koji je lokalni episkop potpisao, postojanje trona (gornjega mjesta) na kojem svećenik nikada ne sjedi i, možda najvažnije, sam čin hirotonije prezbitera i njegovo poslanje u određenu parohiju prema slobodnoj odluci nadležnoga arhijereja, »onako kako on smatra, polažući računa samo Gospodu ${ }^{36}$. Sve to govori o težnji Crkve da ukaže na bitnu ovisnost svećeničke liturgije o episkopskoj. Time dolazimo do zaključka da parohija nije autonomna ni puna euharistijska zajednica, nego je objava i širenje jedne i jedine episkopske, katedralne euharistije. Prezbiter, analogno tomu, služi euharistiju u ime svoga episkopa, na što ga upućuje i sam episkop kada ga rukopolaže. Tijekom čina hirotonije prezbitera, dajući svećeniku dio Agneca u ruke, episkop ga poučava da prima zalog za koji će dati odgovor na strašnom Kristovu sudu. Taj zalog predstavlja opomenu na jedinstvo s episkopom i služenje pod njegovim blagoslovom (»ako on kome dozvoli «) i u njegovo ime (»najpre pomeni Gospode, preosveštenog episkopa našeg «), na određenom području koje i geografski i ekleziološki pripada pastirskoj brizi eparhijskoga arhijereja. Na parohiju dakle episkop iz sintronosa šalje jednoga prezbitera da bi taj tamo, napustivši prezbiterij, postao jerej konkretne kršćanske zajednice. Očigledno je da je svećenik, za razliku od episkopa, u potpunosti usmjeren na zajedništvo i mjesnu Crkvu. To se očituje u tome da svećenik spominje samo svoga lokalnoga episkopa, a ne i metropolita, arhiepiskopa ili patrijarha regionalne Crkve kojoj pripadaju i on i episkop. Zbog toga je u jednoj eparhiji (punoj lokalnoj Crkvi) istinita samo ona euharistija koju služi episkop ili svećenik koji je s njim u koinoniji. Nakon što smo predstavili tumačenje episkopske i prezbiterske službe i njihova međusobnoga odnosa na temelju pretpostavki pravoslavne predaje, razmotrit ćemo njihovu praktičnu primjenu u suvremenom životu istočne Crkve. Koristimo se prilikom da naglasimo činjenicu da se mnogi elementi pravoslavne teologije službi nalaze integrirani u usvojenim dokumentima pravoslavno-katoličkoga dijaloga, osobito u Minhenskom (iz 1982. godine) i Valaamskom (iz 1988. godine), kao zajednički za obje strane. ${ }^{37}$

\footnotetext{
${ }^{36}$ KIPRIJAN, Poslanica 55 (52), 21.

${ }^{37} \mathrm{O}$ tome vidi Z. MATIĆ, Da istinujemo u ljubavi. Zvanični bogoslovski dijalog Pravoslavne i Rimske Katoličke Crkve, Požarevac, 2013.
} 


\section{Aktualna situacija u pravoslavlju}

Ako sada, uvijek imajući na umu spomenute teološke pretpostavke, analiziramo osnovnu aktualnu ekleziološku i kanonsku situaciju u Pravoslavnoj Crkvi, morat ćemo priznati da se nalazimo pred ozbiljnim problemima u svezi s njezinim ustrojem i funkcioniranjem. Ti su problemi vrlo blisko povezani s pitanjem koje je tema našega istraživanja.

Pojedinačno promatrane, obje službe koje analiziramo pretrpjele su izmjene tijekom povijesnoga hoda Crkve prema Kraljevstvu, pa je zbog toga i njihov odnos u crkvenoj praksi prilično promijenjen, a u nekim aspektima i poremećen. Episkopi, svakako, i dalje rukopolažu svećenike, posvećuju žrtvenike i potpisuju antiminse. Prezbiteri pak i dalje čuvaju gornja mjesta svojih lokalnih episkopa u oltaru, spominju ih na liturgiji, ali živi odnos i puna koinonija tih dvaju službi pred velikim su izazovom, na svojevrsnoj su povijesnoj kušnji. Episkop je udaljen i od svećenika i od vjernoga naroda, te je zato usamljen u djelovanju i odlučivanju. Eparhije postaju goleme. Episkop se sve manje razumije i prihvaća kao onaj koji je po povlastici liturg svoje zajednice, sve je manje njezino bogoslužno središte, sve se manje smatra ocem i arhijerejom svomu stadu, a sve više službenikom s kojim se komunicira na administrativnoj razini. Dovoljno je pogledati aktualni Veliki tipik koji tri i pol stranice (od 270.) posvećuje čudnim i rijetkim događajima: episkopskom posjetu parohijama ili parohovom služenju liturgije s vladikom..$^{38}$ Opisujući obredni dio kanonskoga posjeta arhijereja, tipik ne zaboravlja naglasiti: $\gg$ Ako bi arhijerej došao u hram za vreme bogosluženja, liturgije, večernje ili jutrenja, ne prekida se bogosluženje. « ${ }^{39}$ Bogoslužni, ali i svi drugi vidovi života parohije, teku mimo episkopa do te mjere da i njegov slučajan dolazak predstavlja ometanje toga tijeka. I drugi događaj koji se opisuje u toj knjizi, služenje liturgije s episkopom, koje se do sitnica objašnjava, pokazuje ponovno koliko je taj događaj postao rijedak i neprirodan u iskustvu parohijske zajednice. Dolazak episkopa opisuje se kao posjet bitnoga i uvaženoga gosta kojem svećenik ustupa služenje euharistije iz kurtoazije, koga treba uvažiti tih nekoliko izvanrednih sati u životu parohije kojima redovno i prirodno predsjeda i rukovodi svećenik. Parohije su, očigledno, postale autonomne, zatvorene, sebi dovoljne. To se događa i svećenicima. Njihov odnos s episkopom sve se više svodi na mrtvu administrativnu korespondenciju. Postoje eparhijska tijela i organi (Eparhijski savjet, Eparhijski upravni odbor, Crkveni sud Eparhije) čiji su članovi i svećenici (i laici), ali ti odbori i savjeti više imaju estetsku nego egzistencijalnu ulogu.

\footnotetext{
${ }^{38}$ Usp. Veliki tipik (ustav crkveni). Sastavio protojerej Vasilije Nikolajević, Beograd, ${ }^{4} 1984$., posebno ulomke »Kako se dočekuje Arhijerej, kad posećuje hramove po gradovima i selima «, 260-261., i zadnje stranice knjige »Služenje Sv. Liturgije sa Arhijerejem «.

${ }^{39}$ Isto, 261.
} 
Birokratizacija je potisnula koinoniju, subordinacionizam i strah zauzimaju mjesto slobodnomu ljubavnomu dijalogu.

Budući da se episkopsku vlast više nije moglo graditi na temelju euharistijskoga poretka i ljubavnoga očinskoga odnosa arhijereja s njegovom zajednicom, školsko bogoslovlje počelo je episkopov autoritet izvlačiti iz relacijske ontologije i objektivizirati ga. Njegov autoritet prestao je izlaziti iz zajednice i postao je nametnut $^{40}$. Odnosi su se počeli opisivati pojmovima nadređenosti i podređenosti, a ne egzistencijalne međuuvjetovanosti. U spomenutim okvirima postoji najveća opasnost da se pravoslavni episkopocentrizam preobrazi u episkopomonizam. Tada se naime kao reakcija, u pravilu, javljaju različite tzv. karizmatske (duhovne) dimenzije Crkve. Određeni duhovnici, starci, najčešće iz monaških redova, pozivajući se na svoje, individualne karizme, pokušavaju episkopu i, osobito, svećeniku (parohu) oteti kanonski autoritet. Istinita je tvrdnja da »episkopomonizam hrani klirikomonizam i neizbežno izaziva laikomonizam $\ll{ }^{41}$.

U životu i praksi Crkve još se uvijek ipak čuva zdravo poimanje značenja episkopa, kao i svećenika, zahvaljujući osjećaju vjernih i njihovoj otvorenoj vezanosti za predaju. Koliko će to još opstati? Bogoslovlje naime ne uspijeva pratiti te segmente života Crkve i nema izraženu svijest niti nalazi, a ponajmanje artikulira jasne razloge koji bi potvrdili mjesto episkopa i svećenika, kao i njihov odnos u Crkvi danas. Ako se pak ta načela ne budu mogla teološki jasno i precizno izraziti, pojavit će se pitanje svrhovitosti tih službi. To će posebno biti pojačano u civilizaciji utilitarističkoga egoizma (je li barem jedna od tih službi suvišna s obzirom na to da njihovo održavanje nije financijski opravdano), što bi moglo imati nesagledive posljedice za teologiju službi u Crkvi i, općenito, za pravoslavnu ekleziologiju.

\section{Sinteza: neki praktični prijedlozi}

Teologija crkvenih službi naime izravno je povezana s realnostima predaje i autoriteta, ali su upravo te dvije kategorije u suvremenom svijetu na najjačem udaru i pod ozbiljnom sumnjom ${ }^{42}$. Svjedočanstvo o episkopu i svećenicima kao duhovnim ocima i učiteljima, o ljubavi kao jedinom temelju njihova odnosa koji se treba preliti u

\footnotetext{
${ }^{40}$ Ovdje se otvara velik problem izbora episkopa i njihova slanja u određenu zajednicu, koji će se morati staviti na dnevni red pitanja suvremene pravoslavne ekleziologije, ali ta tematika nadilazi okvire ovoga istraživanja.

${ }^{41}$ S. JAGAZOGLU, Kriza sabornosti, 79.

${ }^{42} \mathrm{Na}$ sažet, ali izravan način o tome svjedoči Dotolo: »U krizi posredovanja autoriteta i načela tradicije se dakle dohvaća završetak predmodernog poretka obilježenog sviješću o stalnom odnosu $\mathrm{s}$ transcendencijom, s božanskim Bitkom. « C. DOTOLO, Moguće kršćanstvo. Između postmoderniteta i religioznog traganja, Zagreb, 2011., 23.
} 
sve sfere eparhijskoga ili parohijskoga života ostat će mrtvo slovo na papiru ako ne zaživi u spomenutim crkvenim entitetima. Može se prilično uvjereno ustvrditi da opstanak takozvane euharistijske ekleziologije (koju je teološki artikulirao Nikolaj Afanasiev ${ }^{43}$, ali uz kritičke opaske metropolita Zizioulasa ${ }^{44}$ ) ponajviše ovisi o rješenju problema odnosa prezbiterske i episkopske liturgije, odnosno o odnosu svećenika i episkopa. Načelo euharistijske ekleziologije koje glasi tamo gdje je euharistija, tamo je i Crkva treba dakle dodatna pojašnjenja koja se odnose na točno navođenje obvezne prisutnosti četiriju eshatoloških službi bez kojih nema euharistije, a time ni Crkve. To znači da se parohija ne može nazvati Crkvom u punom ekleziološkom značenju te riječi.

Kako bi se takvo teološko pojašnjenje moglo provesti u djelo? Put prema tomu cilju povezan je i s nekim konkretnim praktičnim reformskim potezima. Samo ćemo navesti neke od njih, svjesni da bi se elaboracija tih prijedloga morala povjeriti čitavom tijelu Crkve i da bi tražila dugotrajnu analizu.

Prvi bi bio uspostavljanje parohije kao žive i stvarne liturgijske zajednice ${ }^{45}$ i njezina bliska povezanost $\mathrm{s}$ episkopom. ${ }^{46}$ Parohije $\mathrm{s}$ golemim brojem nominalnih vjernika u mnogočemu paraliziraju euharistijski etos Crkve. To je posebno vidljivo u gradskim sredinama u kojima se crkvenost odavno preobrazila u religioznost i gdje je svećenik odavno postao činovnik mrtvoga ritualizma koji servisira individualne religiozne potrebe ljudi koji nisu članovi njegove euharistijske zajednice jer ne sudjeluju u njezinu životu. Oni pak koji jesu stalni članovi liturgijske zajednice pasivizirali su se do anonimnosti.

Drugi prijedlog neizostavno bi morao podrazumijevati značajno smanjenje eparhija. Time bi sve crkvene službe lakše povratile svoja izvorna značenja. Pitanje financijskoga funkcioniranja dijeceze ipak bi moralo biti i ostati drugotno.

Treći korak, možda i najteži, morao bi biti usmjeren na preispitivanje aktualnoga načina postavljanja klerika i na pokušaj da se u izboru svećenika sve ozbiljnije sluša vox populi. Trenutačno, s obzirom na praksu izbora episkopa iz monaških redova, taj treći reformski potez mogao bi se protezati samo na izbor svećenika i đakona, ali bi to bio vrlo važan korak prema aktualizaciji koinonijskoga načina postojanja u

${ }^{43}$ Usp. N. AFANASJEV, Trpeza Gospodnja, Cetinje, 1996., kao i N. AFANASJEV, Crkva Duha Svetoga, Vršac, 2003.

${ }^{44}$ Usp. J. ZIZIJULAS, Pravoslavlje, 42-44.

${ }^{45}$ Usp. P. EVDOKIMOV, 'Luda' ljubav Božija, Hilandar, 1993.

${ }^{46}$ Najprije bi se u gradskim sredinama moglo pokušati s praksom zajedničkih bogoslužja, arhijerejskih euharistija u katedralnoj crkvi o velikim praznicima ili u konkretnim parohijskim crkvama posebnim liturgijskim danima (crkvena slava). 
koje se pravoslavlje zaklinje. Smatramo naime da bi se mjesto i uloga prezbiterija u životu eparhije mogla uspostaviti upravo procesom bitne uključenosti prezbitera u izbor eparhijskoga arhijereja.

\section{Zaključak}

Tema koju smo analizirali vrlo je aktualna, ali i vrlo delikatna. Jasno je da problem odnosa episkopa i prezbitera tek očekuje duboku analizu u suvremenoj pravoslavnoj teologiji, ${ }^{47}$ a s njom u vezi i eventualno preosmišljavanje, svojevrsni aggiornamento. Odgovarajuće prilagođavanje uvjetovano je i crkvenom situacijom i krizom službi, ali i novim sociopolitičkim okolnostima pluralističkoga društva. Izražavamo uvjerenost da će teologija Crkve moći iz vlastitih predajnih riznica pronaći one eshatološke elemente koji će predstavljati sigurne oslonce za napredovanje crkvenoga života u novim i izrazito izazovnim trenutcima njezine povijesti. Neka jedan prijedlog zaključka budu riječi o. Alexandera Schmemanna koji o temi kojom se bavimo sasvim iskreno piše u svom Dnevniku. Evo kako jedan pravoslavni svećenik i vrsni teolog nakon trideset godina prezbiterske službe vidi svoj odnos s episkopom:

$\gg$ Pitam se (...) u čemu je potreba da imamo Episkopa, a sa druge strane, sa mnogo dubljeg nivoa koji čini Crkvu Crkvom - zašto su oni potrebni i korisni? (...) Episkopi su tvrda stena i to u dva značenja te reči. U negativnom značenju, stena je slepi autoritet, strah, samouverenost itd i zato dolazi do problema kada treba izaći na kraj sa živom Crkvom. U pozitivnom značenju (...) oni su potrebni kao stene. Njihov zadatak je da budu nosioci konzervativizma u Crkvi, u najdubljem smislu te reči, jer je Crkva ta tvrda stena. (...) Raditi sa episkopima uvek je teško, ali znamo da je u Crkvi teškoća dobra stvar i da 'nama kroz mnoge nevolje valja ući u Carstvo'. Pošto sam proveo život sa ovakvim teškoćama, verujem $\mathrm{u}$ episkope istom onom verom kojom, uprkos svemu, verujem $\mathrm{u}$ Crkvu. $\ll{ }^{48}$

Neprekidno tkanje osobnih odnosa u međusobnom egzistencijalnom povjerenju, sa sviješću da su najodgovorniji za životnu silu Crkve - njezinu euharistiju i da postoje jedni radi drugih: u tome se ogleda odnos episkopa i prezbitera (kao i svih ostalih službi u Crkvi). Samo na taj način moguće je prevladati suvremena iskušenja pravoslavlja: episkopomonizam i prezbiterijanizam. Na tome su pozvani surađivati kršćani svih prostora, cijele ekumene jer izmi ne poznaju konfesionalne granice.

\footnotetext{
${ }^{47}$ Metropolit Zizioulas smatra da je »eklisiološki status parohije jedan od temeljnih problema, kako istočne, tako i zapadne eklisiologije «. I. ZIZIOULAS, L'essere ecclesiale, Magnano, 2007., 254.

${ }^{48}$ Dnevnik oca Aleksandra Šmemana, Beograd - Trebinje, 2007., 233. Usp. i A. ŠMEMAN, Naš život u Hristu, Hristov život u nama, Beograd, 2007., 344-345.
} 


\section{RELAZIONE TRA MINISTERO EPISCOPALE E MINISTERO SACERDOTALE NELL'ORTODOSSIA}

\section{Zlatko MATIĆ*}

Riassunto: Il presente articolo concentra la sua attenzione sulla teologia dei ministeri ecclesiali (soprattutto del vescovo e del presbitero) nella Chiesa ortodossa. La ricerca è strutturata in tre parti principali. Nella prima parte si analizza l'evoluzione dei ministeri summenzionati, la seconda parte si propone di osservare in particolare la situazione attuale nell'ortodossia, mentre nella terza parte, l'autore presenta un suo tentativo di prospettare il ministero del vescovo come ministero primariamente communionale, relazionale nei confronti di tutta la Chiesa. Cosi, le conclusioni affermano la prospettiva dell'ecclesiologia di comunione come il naturale quadro entro cui dobbiamo collocare tutti i ministeri della Chiesa.

Parole chiave: vescovo, presbitero, ministeri ecclesiali, escatologia, ordinazione, $\gg k o i-$ nonia $\ll$.

* Asst. Prof. Zlatko Matić, Ph. D., Faculty of Orthodox Theology, University of Belgrade, Mije Kovačevića 11b, 11060 Beograd, Serbia, zmatic@bfspc.bg.ac.rs 